\title{
Decreased Podocyte Vesicle Transcytosis and Albuminuria in APC C-Terminal Deficiency Mice with Puromycin-Induced Nephrotic Syndrome
}

\author{
Saaya Hatakeyama ${ }^{1}$, Akihiro Tojo ${ }^{1, *}$, Hiroshi Satonaka ${ }^{1}$, Nami O. Yamada ${ }^{2} \mathbb{D}$, Takao Senda ${ }^{2}$ \\ and Toshihiko Ishimitsu ${ }^{1}$ \\ 1 Department of Nephrology \& Hypertension, Dokkyo Medical University, Tochigi 321-0293, Japan; \\ saaya.hatakeyama@gmail.com (S.H.); satonaka@dokkyomed.ac.jp (H.S.); isimitu@dokkyomed.ac.jp (T.I.) \\ 2 Department of Anatomy, Gifu University, Gifu 501-1193, Japan; nyamada@gifu-u.ac.jp (N.O.Y.); \\ tsenda@gifu-u.ac.jp (T.S.) \\ * Correspondence: akitojo@dokkyomed.ac.jp; Tel.: +81-282-86-1111
}

\section{check for} updates

Citation: Hatakeyama, S.; Tojo, A.; Satonaka, H.; Yamada, N.O.; Senda, T.; Ishimitsu, T. Decreased Podocyte Vesicle Transcytosis and Albuminuria in APC C-Terminal Deficiency Mice with Puromycin-Induced Nephrotic Syndrome. Int. J. Mol. Sci. 2021, 22, 13412. https://doi.org/10.3390/ ijms222413412

Academic Editors: Andrea Huwiler and Carolyn M. Ecelbarger

Received: 29 October 2021

Accepted: 10 December 2021

Published: 14 December 2021

Publisher's Note: MDPI stays neutral with regard to jurisdictional claims in published maps and institutional affiliations.

Copyright: (C) 2021 by the authors. Licensee MDPI, Basel, Switzerland. This article is an open access article distributed under the terms and conditions of the Creative Commons Attribution (CC BY) license (https:// creativecommons.org/licenses/by/ $4.0 /)$.

\begin{abstract}
In minimal change nephrotic syndrome, podocyte vesicle transport is enhanced. Adenomatous polyposis coli (APC) anchors microtubules to cell membranes and plays an important role in vesicle transport. To clarify the role of APC in vesicle transport in podocytes, nephrotic syndrome was induced by puromycin amino nucleoside (PAN) injection in mice expressing APC1638T lacking the C-terminal of microtubule-binding site (APC1638T mouse); this was examined in renal tissue changes. The kidney size and glomerular area of APC1638T mice were reduced $(p=0.014)$; however, the number of podocytes was same between wild-type (WT) mice and APC1638T mice. The ultrastructure of podocyte foot process was normal by electron microscopy. When nephrotic syndrome was induced, the kidneys of WT+PAN mice became swollen with many hyaline casts, whereas these changes were inhibited in the kidneys of APC1638T+PAN mice. Electron microscopy showed foot process effacement in both groups; however, APC1638T+PAN mice had fewer vesicles in the basal area of podocytes than WT+PAN mice. Cytoplasmic dynein-1, a motor protein for vesicle transport, and $\alpha$-tubulin were significantly reduced in APC1638T+PAN mice associated with suppressed urinary albumin excretion compared to WT+PAN mice. In conclusion, APC1638T mice showed reduced albuminuria associated with suppressed podocyte vesicle transport when minimal change nephrotic syndrome was induced.
\end{abstract}

Keywords: podocyte; vesicle transport; microtubule; nephrotic syndrome; adenomatous polyposis coli; glomerular filtration barrier

\section{Introduction}

The first electron microscopy observation of glomerulus in 1955 prompted several theories concerning glomerular filtration involving detection of the slit membrane as a glomerular filtration barrier [1] and transepithelial transport via podocyte vesicles [2]. Unfortunately, the concept of transepithelial transport via podocyte vesicles has long been neglected. The glomerular basement membrane has been recognized as an essential barrier [3]. The observation of a zipper-like structure in the slit membrane [4] followed by the detection of nephrin as a slit membrane molecule [5] confirmed the concept that albumin leaks through the slit membrane pores in nephrotic syndrome [6,7]. Later, progression of proteinuria in laminin beta 2 mutant mice again reminded us of the importance of GBM as a glomerular filtration barrier [8,9]. The mystery of the glomerular filtration barrier (GFB) is why it does not clog [10] when filtering $3 \mathrm{~g}$ of albumin daily in the primary urine, even under normal conditions [11]. Gel hypotheses and electrokinetic models have been proposed to solve the mystery of GFB clogging [10,12], but not enough attention has been paid to the mechanism of transcytosis in podocytes. 
We reestablished the concept of albumin filtration through the podocyte cell body in minimal change nephrotic syndrome (MCNS) [13] and demonstrated the selective albumin transport in podocytes via FcRn receptors [14]. Several albumin transport mechanisms, including clathrin-mediated endocytosis [15], megalin-mediated endocytosis [16], caveolaemediated endocytosis [17] and macropinocytosis [18], have been described [19]. Electron microscopic observation of podocyte of MCNS patients showed numerous vesicles [19-21], and glomeruli under conditions of MCNS showed increased motor proteins, including cytoplasmic dynein 1, myosin IXa (Myo9a) and myosin VIIb (Myo7b) [22]. Cytoplasmic dynein transports cargo along the microtubules toward the minus end, attached under the adhesion junction [23,24]; podocyte vesicle transport may thus explain selective albuminuria in MCNS [19,22].

Adenomatous polyposis coli (APC) is a tumor suppressor protein in colon cancer [25] and an anchor protein that binds to $\beta$-catenin with postsynaptic density postsynaptic density (PSD)-93/95 in the adhesion complex of the synaptic membrane [26,27]. APC also binds to both the actin and microtubule plus-ends [28], thereby positioning a microtubulebased transport pathway to carry receptor proteins to postsynaptic regions [27]. APC1638T mice express a mutant APC protein lacking the C-terminal side after 1639 amino acids, preventing binding with PSD-95, discs large (DLG), microtubules and end-binding protein 1(EB1) [29-32]. Glomerular podocytes contain similarities to neurons and express PSD93 [33], so in the present study, we investigated the morphological changes in podocyte microtubule and vesicle transport in APC1638T mice with PAN-induced MCNS and discussed the importance of podocyte vesicle transport as a mechanism of selective albuminuria.

\section{Results}

2.1. Kidney Size, Glomerular Volume, and Podocyte Number and Structure in APC Mutant Mice

The kidney of APC1638T mice was examined by PAS staining, and the size of the kidney and glomerulus seemed to be smaller than in wild-type mice (Figure 1). The size of the glomeruli and number of podocytes in each glomerulus were calculated using semithin sections of EPON-embedded tissue stained with $0.05 \%$ Toluidine Blue solution. The glomerular cross-sectional area of APC1638T mice was smaller than that of wild-type mice $(p=0.014)$; however, the number of podocytes was not significantly different between wild-type (WT) mice and APC1638T mice (Figure 2). The ultrastructure of the podocyte did not differ markedly between WT and APC1638T mice, and the foot process was preserved in APC1638T mice (Figure 3). 


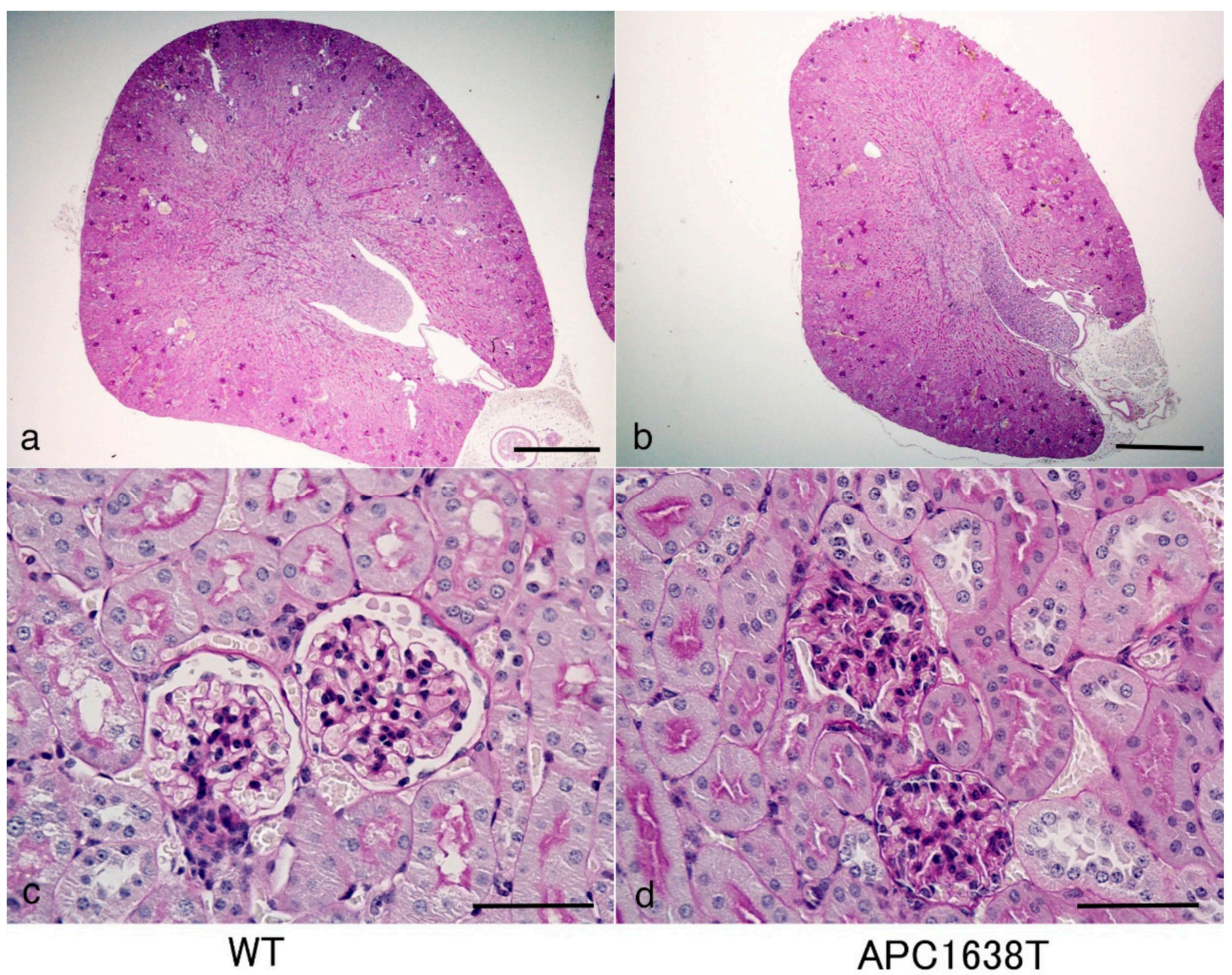

Figure 1. Periodic acid Schiff (PAS) staining of the kidney of wild-type (WT, $(\mathbf{a}, \mathbf{c}))$ and APC1638T mice (b,d). The bars indicate $500 \mu \mathrm{m}(\mathbf{a}, \mathbf{b})$ and $50 \mu \mathrm{m}(\mathbf{c}, \mathbf{d})$. 


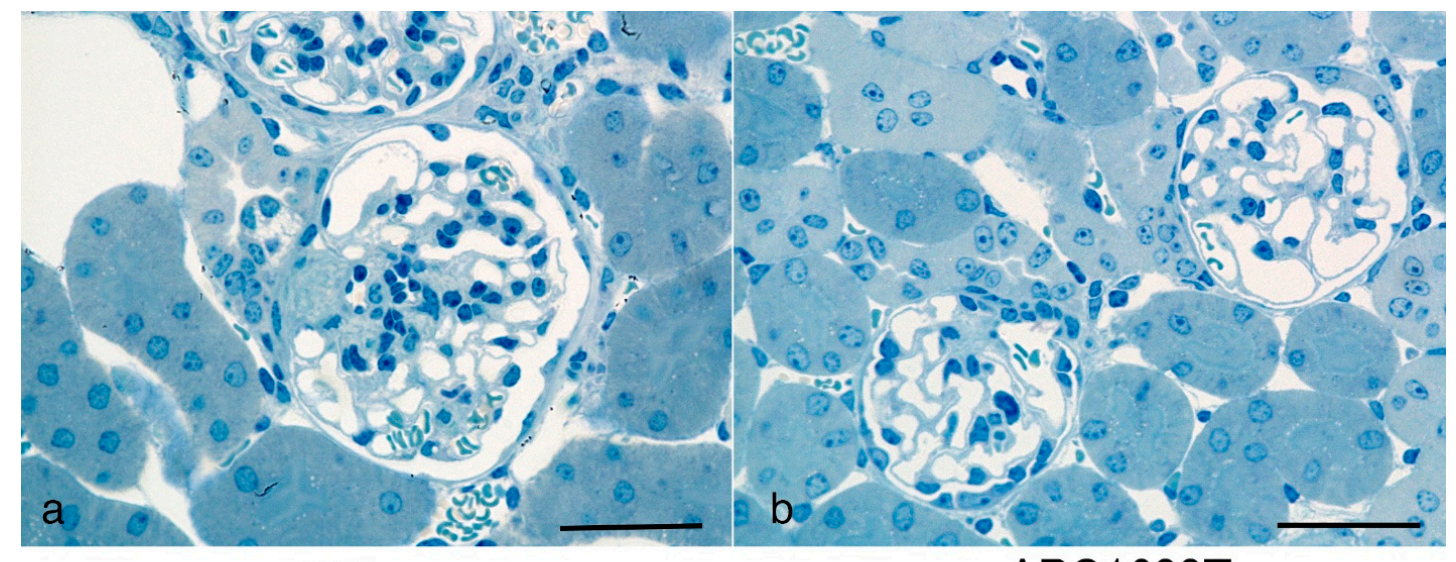

WT

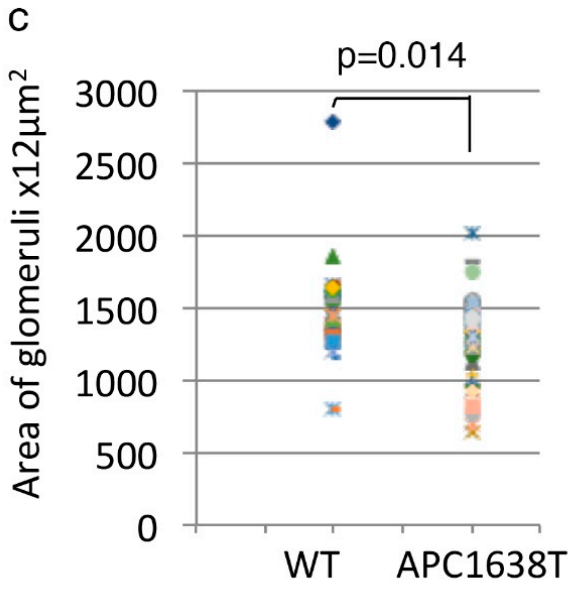

d

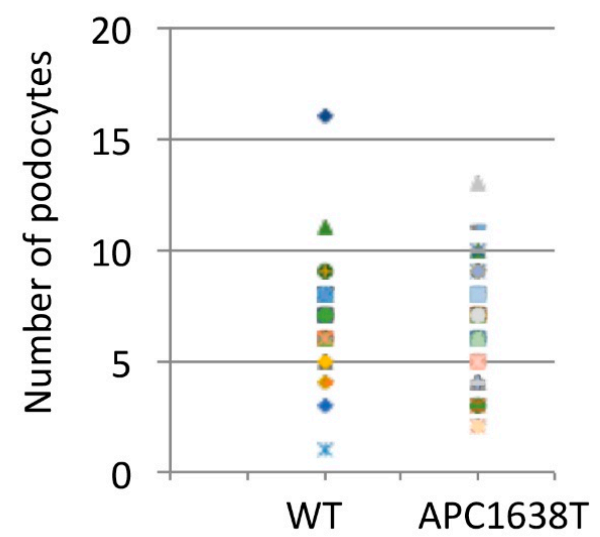

Figure 2. Toluidine blue staining of EPON-embedded renal sections from wild-type (a) and APC1638T mouse (b). The bars indicate $50 \mu \mathrm{m}(\mathbf{a}, \mathbf{b})$. The area of glomerular tuft were measured using Image Pro software (c), and the number of podocytes (d) were measured by counting nucleus of podocyte in each glomerulus from a wild-type mouse ( $\mathrm{n}=32$ glomeruli) and an APC1638T mouse ( $\mathrm{n}=51$ glomeruli).

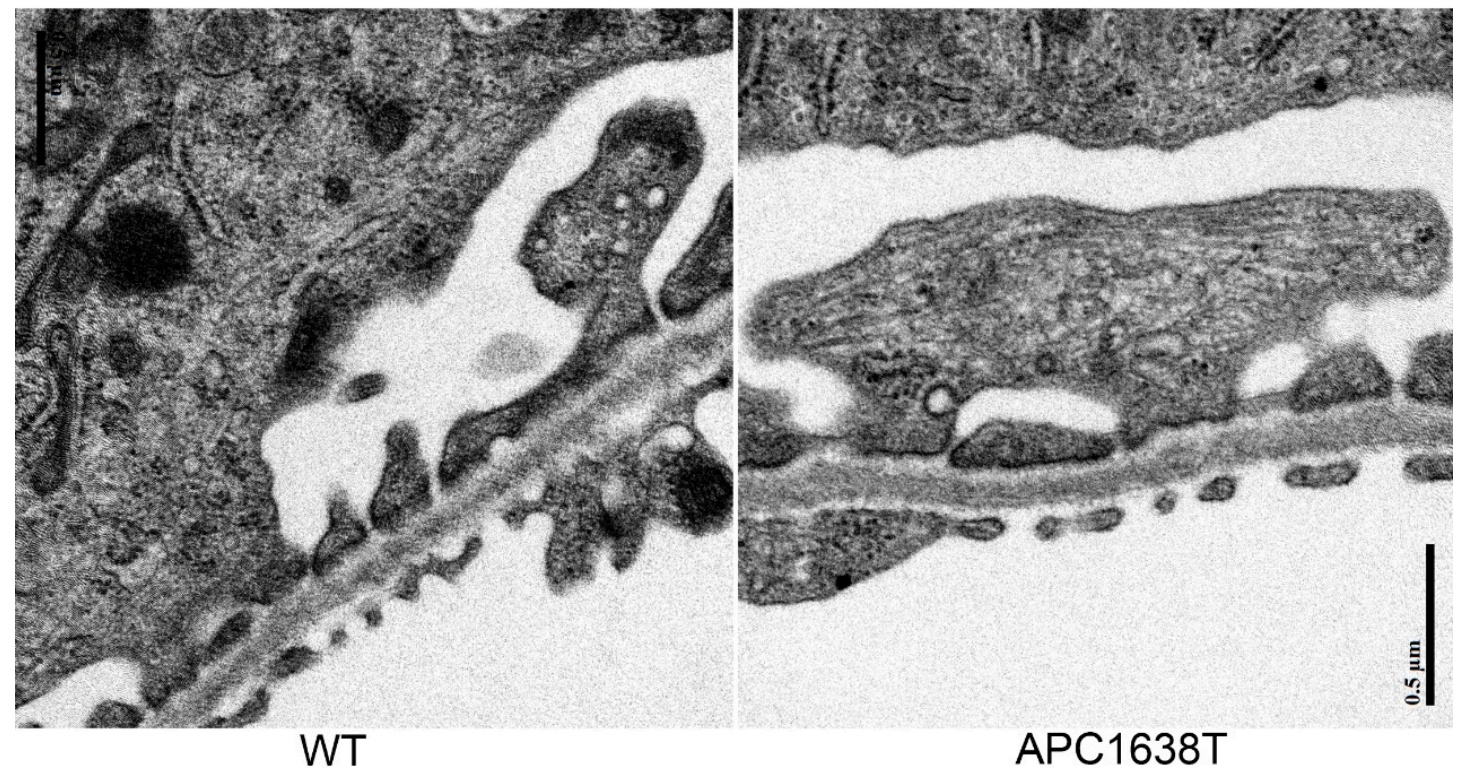

Figure 3. Electron micrograph of podocyte of wild-type (WT) and APC1638T mice. The bar indicates $0.5 \mu \mathrm{m}$. 


\subsection{Kidneys of APC Mutant Mice with PAN-Induced Nephrotic Syndrome}

The kidney in WT+PAN mice was larger than in APC1638T+PAN mice, and many hyaline casts were observed in WT+PAN mice, a finding that was suppressed in APC1638T+PAN mice (Figure 4). Electron microscopic observation showed that podocyte vesicles were located through the cytoplasm of podocytes in WT+PAN mice, even though there were more around the Golgi apparatus, whereas significantly fewer endocytosis vesicles were distributed around the basement membrane area; there were also significantly fewer exocytosis vesicles around the apical membrane area, and enlarged tubular structures were observed around the Golgi apparatus in podocytes in APC1638T+PAN mice compared to WT+PAN mice (Figure 5), suggesting decreased podocyte vesicle transcytosis.

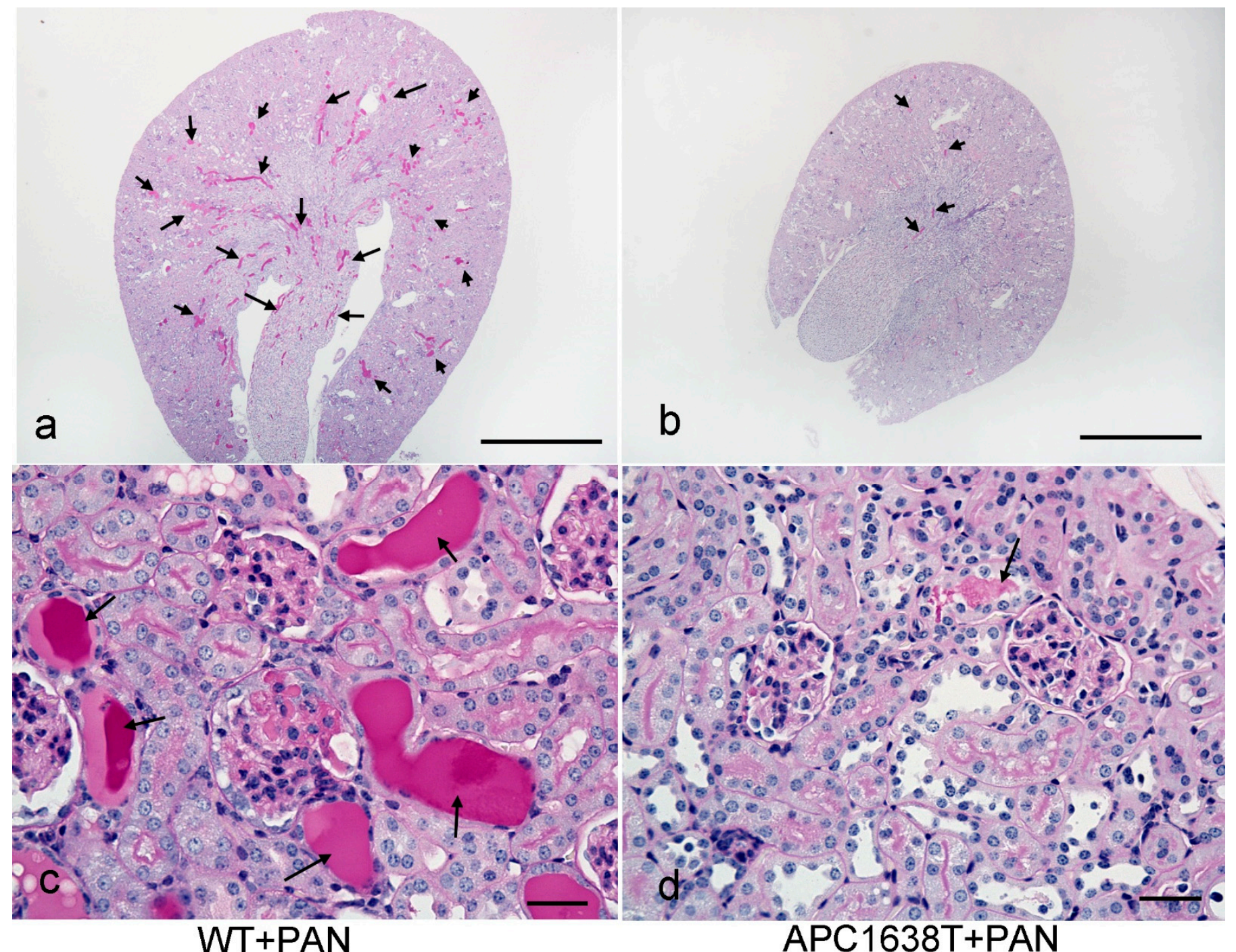

Figure 4. Periodic acid Schiff (PAS) staining of the kidney of wild-type+PAN nephrotic mouse (a,c) and APC1638T+PAN mouse $(\mathbf{b}, \mathbf{d})$. The bars indicate $500 \mu \mathrm{m}(\mathbf{a}, \mathbf{b})$ and $50 \mu \mathrm{m}(\mathbf{c}, \mathbf{d})$. The arrows indicate hyaline casts. 


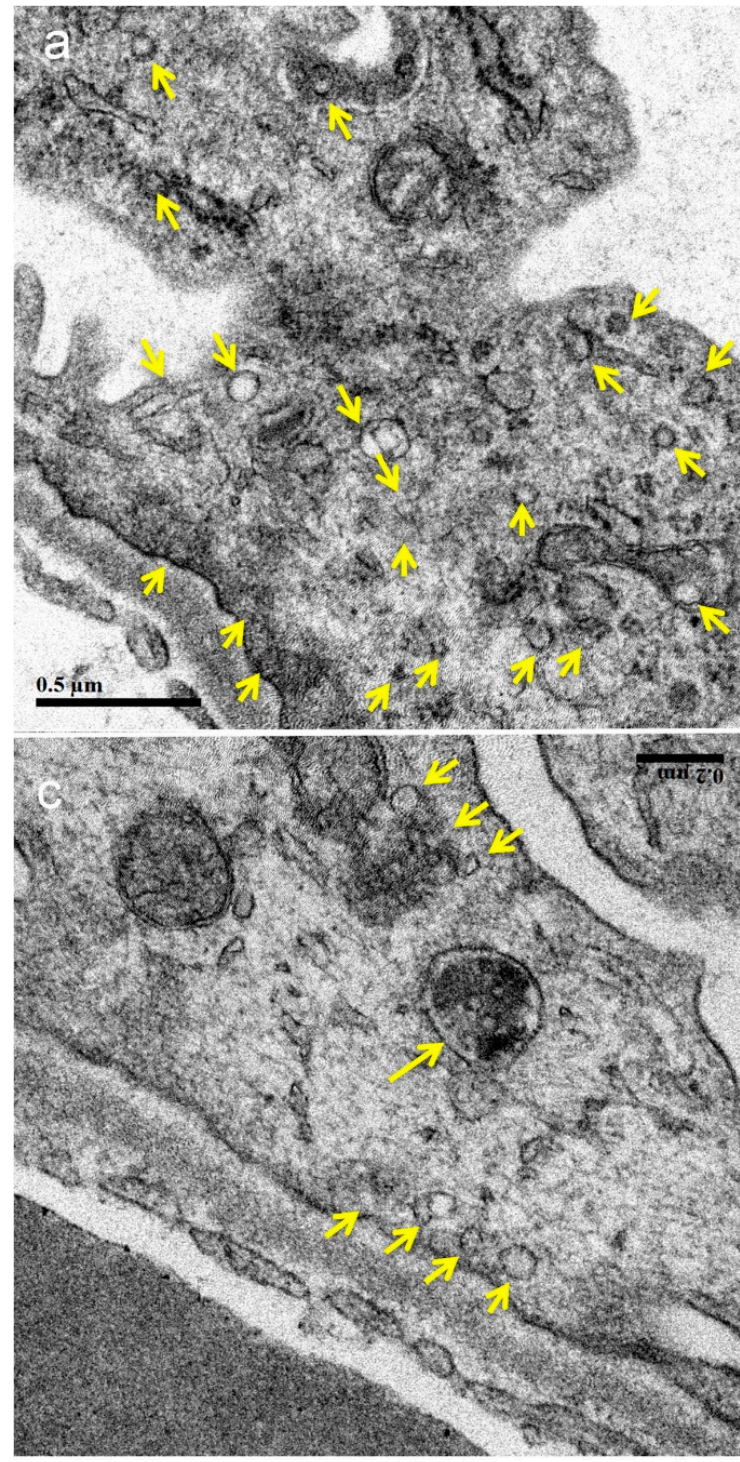

WT+PAN

e
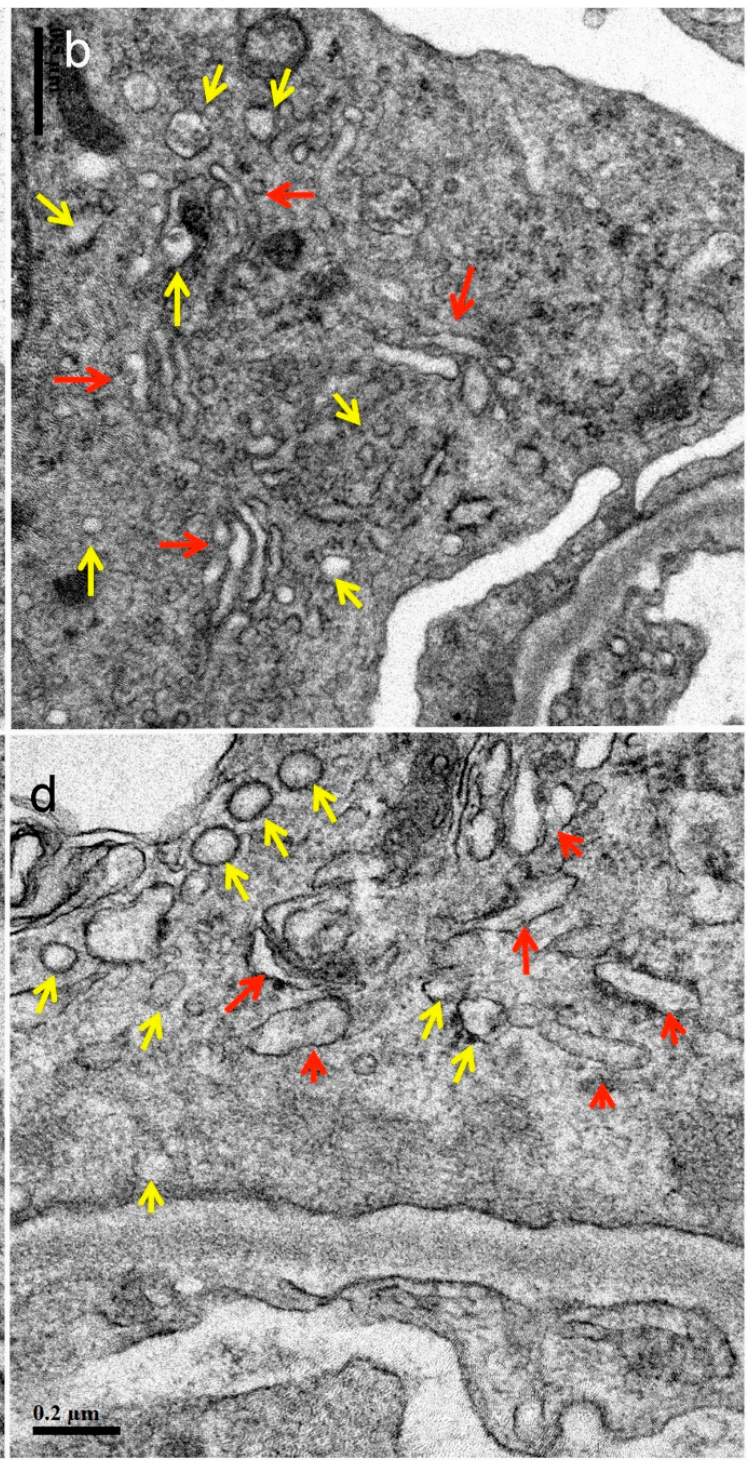

APC1638T+PAN

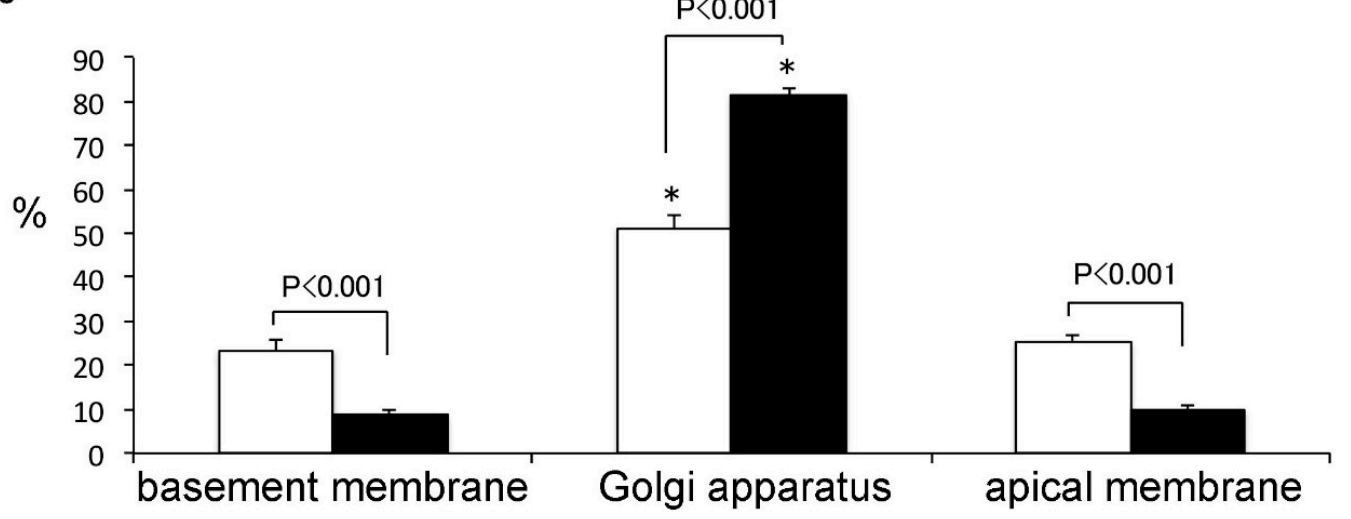

Figure 5. Electron micrograph (a-d) of podocyte and percent vesicle distribution (e) around the basement membrane, Golgi apparatus, and apical membrane of PAN-induced nephrotic syndrome in the wild-type mice (WT+PAN, white bar) and APC1638T mice (APC1638T+PAN, black bar). The yellow arrows indicate endocytosis and transcytosis vesicles, and the red arrows tubular structures related to Golgi apparatus. The bar indicates $0.5 \mu \mathrm{m}(\mathbf{a}, \mathbf{b})$ and $0.2 \mu \mathrm{m}(\mathbf{c}, \mathbf{d}) . \mathrm{n}=25$ podocytes from $3 \mathrm{WT}+\mathrm{PAN}$ mice and $\mathrm{n}=32$ podocytes from 3 APC1638T+PAN mice. ${ }^{*} p<0.001$ vs. basement membrane in each mouse. 
2.3. Cytoplasmic Dynein and $\alpha$-Tubulin Expression in the Podocyte and Albuminuria in APC Mutant Mice with Nephrotic Syndrome

Immunostaining revealed that cytoplasmic dynein- 1 and $\alpha$-tubulin were expressed mainly in the podocytes in glomeruli, and the products of the area and density of immunoreactivity of podocytes were significantly higher in WT+PAN mice than in APC1638T+PAN mice (Figure 6).
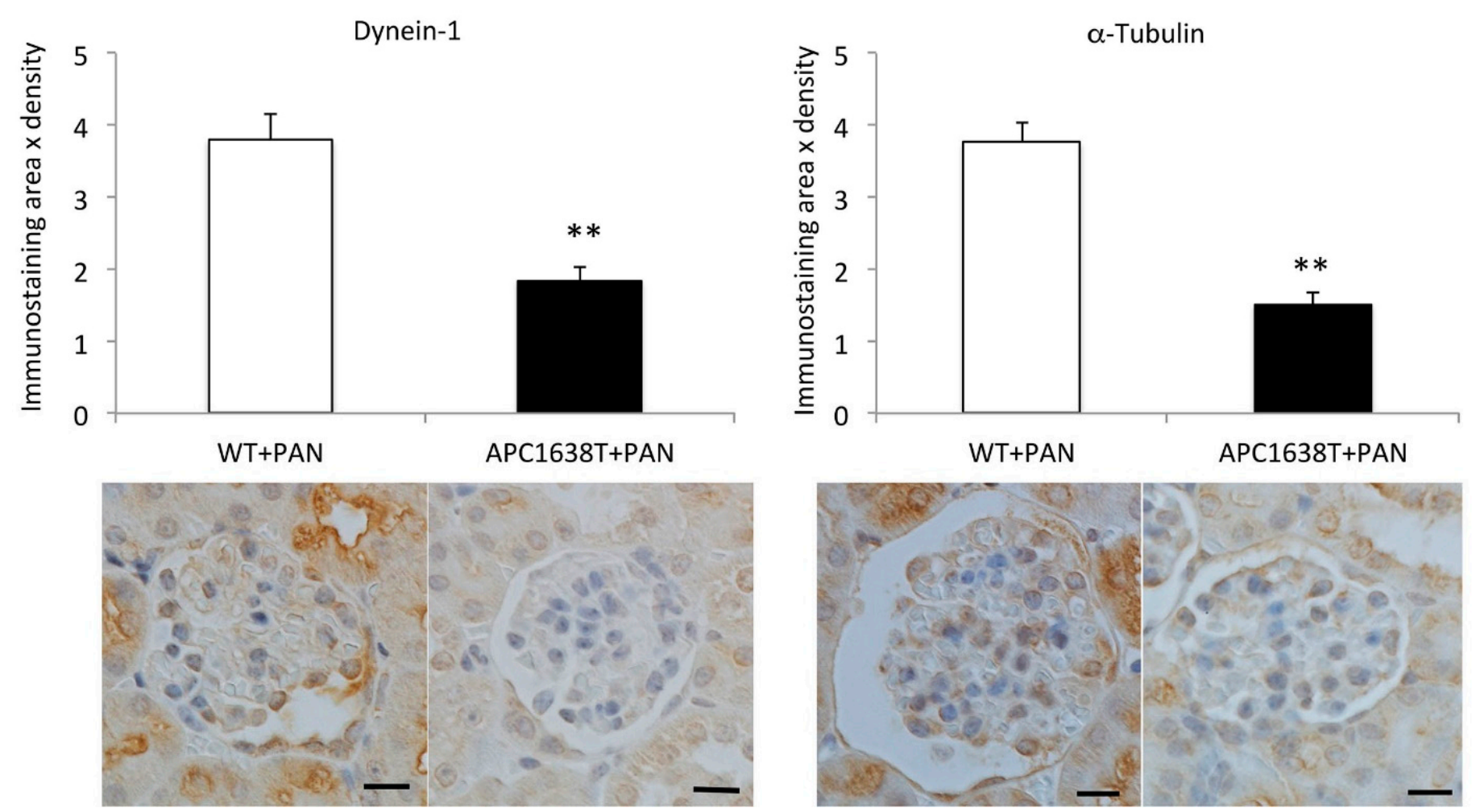

Figure 6. Immunostaining for cytoplasmic dynein-1 and $\alpha$-tubulin in the kidney of PAN-induced nephrotic syndrome in the wild-type mice (WT+PAN) and APC1638T mice (APC1638T+PAN). Immunoreactivity area and density were analyzed by Image-Pro plus software and summarized as bar graphs. $\mathrm{n}=60$ glomeruli in each group of 3 mice ${ }^{* *} p<0.001$ vs. WT+PAN . The bar indicates $10 \mu \mathrm{m}$.

Real-time polymerase chain reaction (PCR) of whole-kidney homogenate demonstrated that $\alpha$-tubulin mRNA was significantly increased in WT+PAN mice compared to WT mice, whereas it did not increase in the kidneys of APC1638T+PAN mice compared to APC1638T mice (Figure 7). Cytoplasmic dynein-1 did not show a significant change in the whole kidney among four groups, probably because it was expressed more strongly in the tubules than in podocytes (Figure 7). Urinary protein excretion did not differ between WT and APC1638T in the normal condition, whereas increased urinary albumin excretion in WT+PAN mice was significantly suppressed in APC1638T+PAN mice (Figure 8). 
Cytoplasmic dynein-1

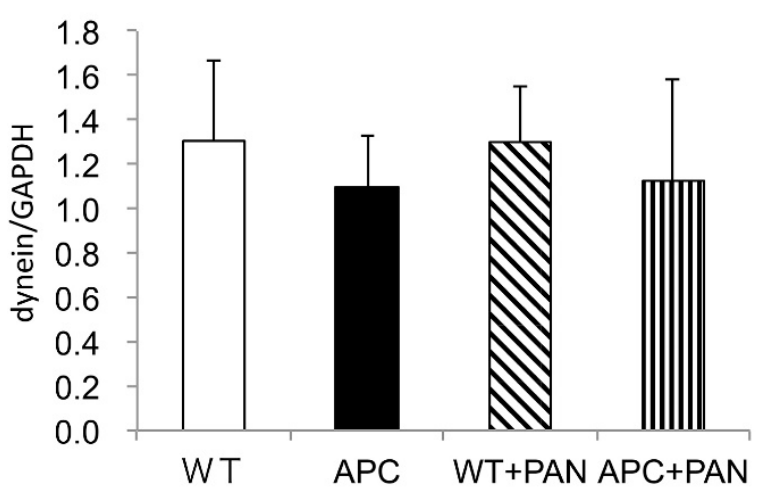

$\alpha$-tubulin

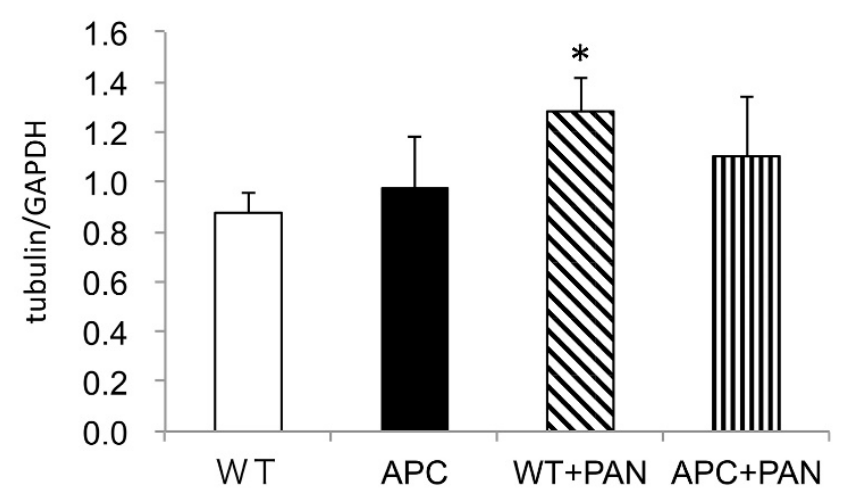

Figure 7. The mRNA expression of cytoplasmic dynein-1 and $\alpha$-tubulin in the kidney of wild-type mice (WT), APC1638T mice (APC), and their PAN-induced nephrotic syndrome (WT+PAN, APC+PAN). $n=2$ measurements from a mouse of $\mathrm{WT}$ and APC, $\mathrm{n}=4$ measurements from 3 mice of $\mathrm{WT}+\mathrm{PAN}$ and APC+PAN. ${ }^{*} p<0.05$ vs. WT.

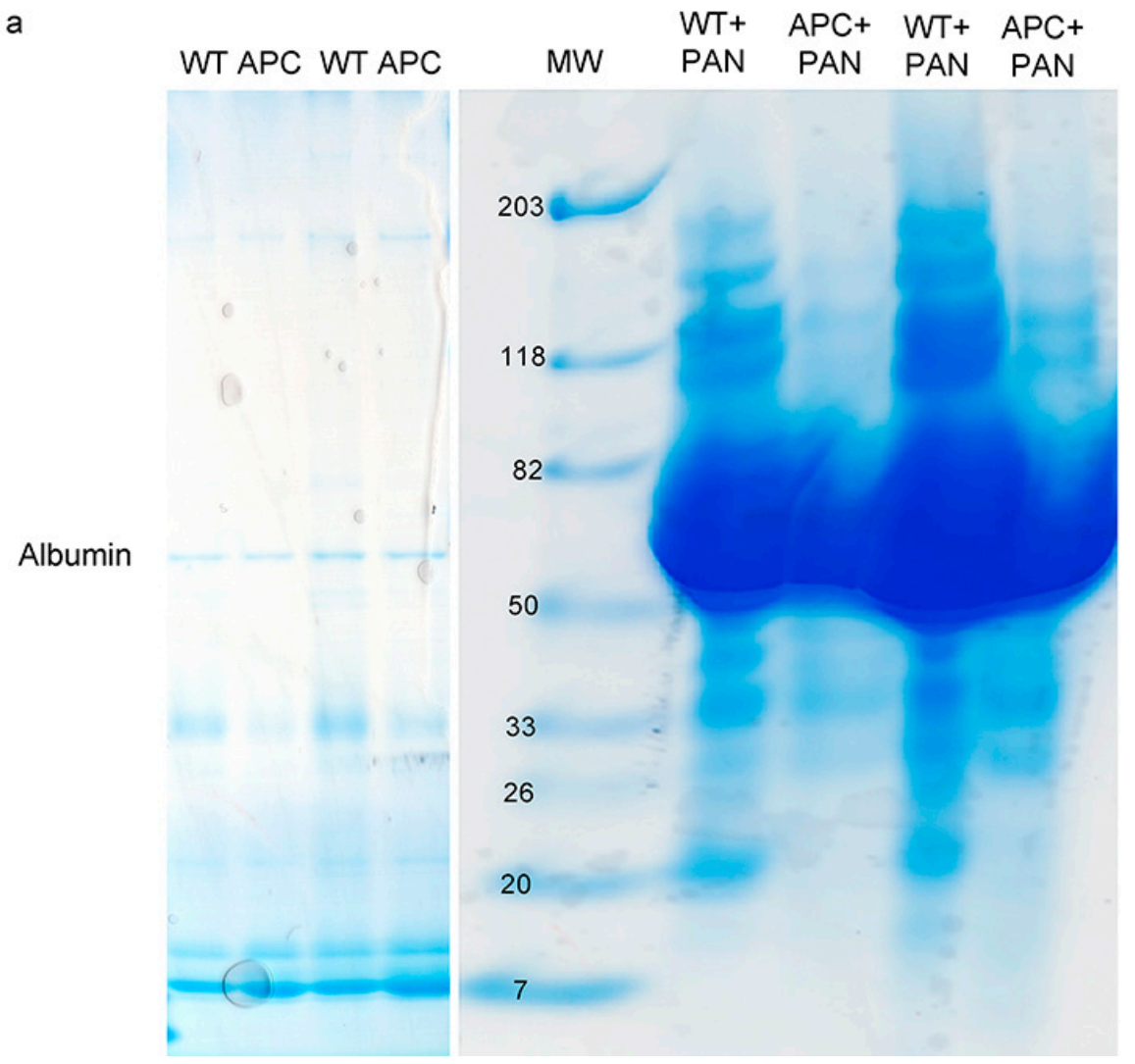

b

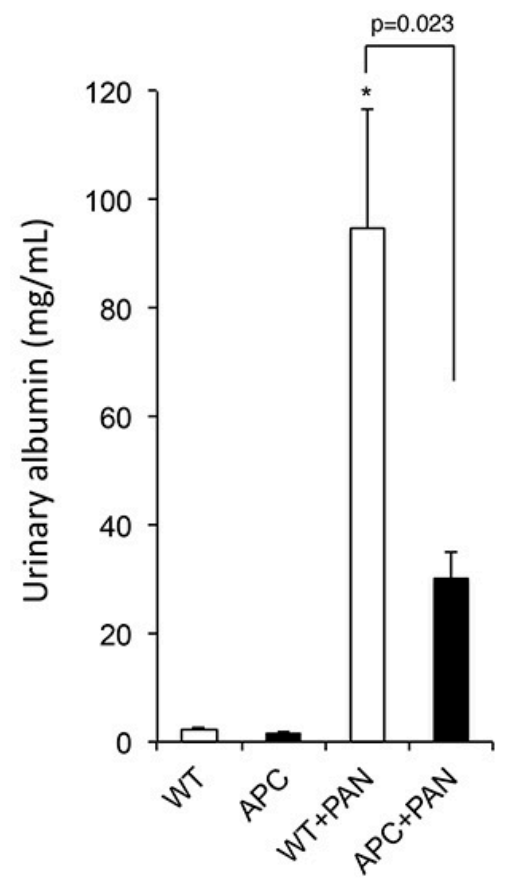

Figure 8. SDS-PAGE analysis of urinary protein (a) and densitometry for urinary albumin (b) of the wild-type mice (WT), APC1638T mice (APC), and their PAN-induced nephrotic syndrome (WT+PAN, APC+PAN). $\mathrm{n}=3$ measurements from 2 mice in $\mathrm{WT}$ and $\mathrm{APC}, \mathrm{n}=4$ measurements from 3 mice in $\mathrm{WT}+\mathrm{PAN}$ and APC+PAN. ${ }^{*} p=0.0034$ vs. WT.

\subsection{Immunofluorescence of Nephrin and Podocin Expression}

To exclude the possibilities of albumin filtration through slit membrane, we performed immunofluorescence of nephrin and podocin expression in the glomeruli. There was no difference in the expression of nephrin and podocin in the glomeruli of WT and APC1638T mice; however, both mice showed reduction of nephrin and podocin in the glomeruli (Figure 9) associated with foot process effacement (Figure 5). As markers of apoptosis, caspase 3, a component of Fas death-inducing signaling complex, and Fas-Ligand were eval- 
uated by immunofluorescence. Except for slight staining for caspase-3 in a few podocytes of WT+PAN mice, there was no significant staining for apoptosis markers in these mice.

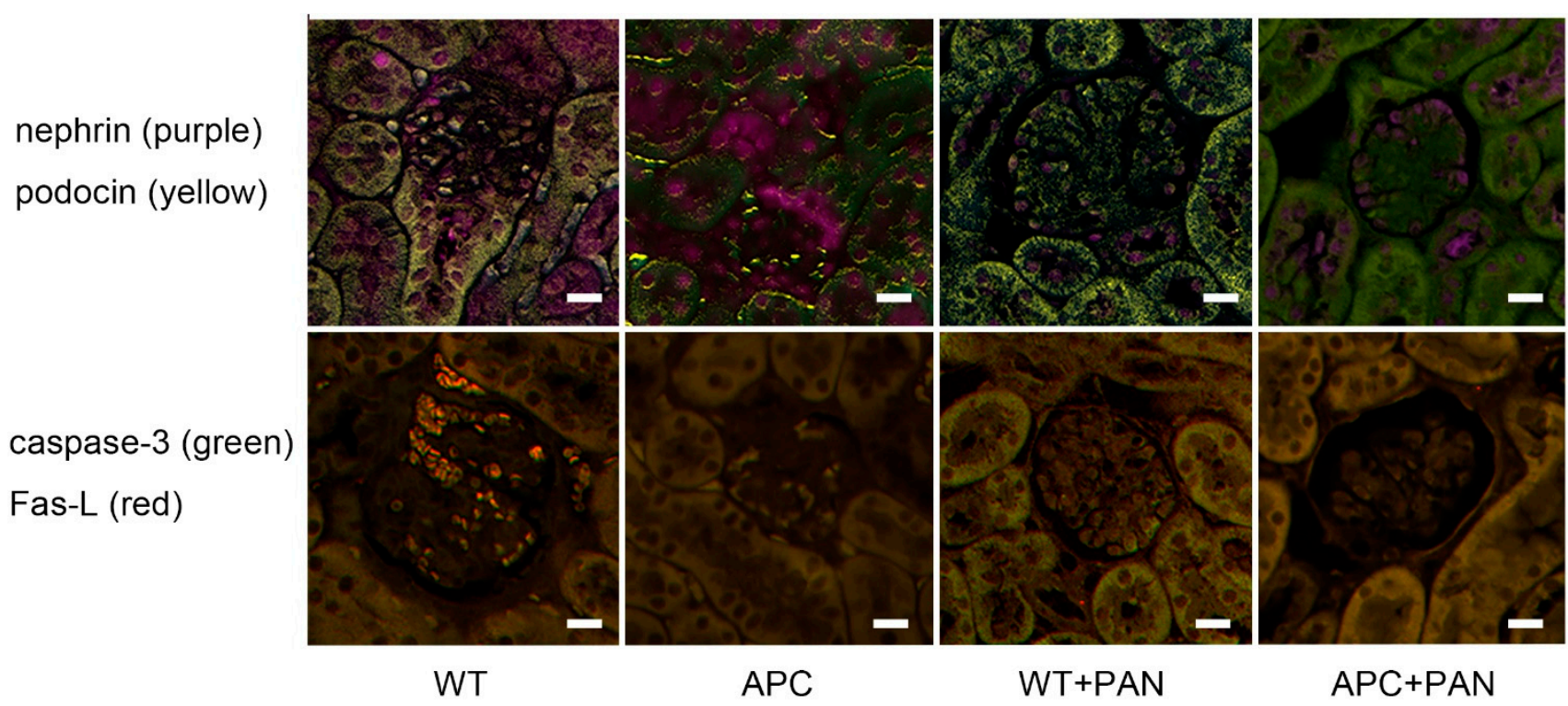

Figure 9. Immunofluorescence for nephrin (purple) and podocin (yellow) in the upper panels, caspase-3 (green) and Fas-Ligand (red) in the lower panels. WT indicates wild-type mice (WT), APC, APC1638T mice, WT+PAN, wild-type mice with PAN-induced nephrotic syndrome, and APC+PAN, APC1638T mice with PAN-induced nephrotic syndrome. The bar indicates $10 \mu \mathrm{m}$.

\section{Discussion}

In the present study, we revealed that microtubule plus end anchor protein APC has an important role in the podocyte vesicle transport in the PAN-induced minimal change nephrotic syndrome, and APC1638T gene mutation reduced podocyte $\alpha$-tubulin expression and reduced basal endocytosis vesicles, resulting in reduction of albuminuria in the PAN-induced nephrotic syndrome.

\subsection{Renal Morphological Change in APC Mutant Mice under Control Conditions}

The kidney size and glomerular cross section area were lower in APC1638T mice than WT mice, but the number of podocytes in the glomerulus was not significantly different (Figures 1 and 2). As podocytes produce type IV collagen of the glomerulus via VEGF production and autocrine stimulation of TGF- $\beta$ [34], the collagen produced in the Golgi apparatus was unable to be transported to the basement membrane where microtubule plus end could not bind with APC in the APC1638T mice, resulting in a reduced glomerular size. Indeed, electron microscopic observation revealed reduced basal vesicles in the podocytes of APC1638T mice (Figure 3). Podocytes are similar to neuronal cells and express PSD-93/95 [33]. APC forms a molecular complex with the NMDAR subunit NRA2 in the vesicles of neuronal cells and binds to microtubules and the kinesin kif3b, which transport the vesicle to the synaptic membrane. The kif3b mutation suppresses NMDAR containing vesicle trafficking to the spine surface membrane, resulting in a reduction in synaptic plasticity and development of schizophrenia-like symptoms [35]. APC also forms a molecular complex with $\mathrm{nAChR}$ in vesicles and plays a role in the transport of $\mathrm{nAChR}$ to the synaptic membrane [27]. The brain weight was shown to be heavier in APC knockout mice [35]. In contrast, APC1638T mice had a preserved $\beta$-catenin binding site in the center of the APC molecule, so cell proliferation via Wnt signaling can be blocked and thereby prevent cancer in APC1638T mice [30,31]. The body weight of APC1638T mice was significantly lower than that of WT mice at all ages [36], correlating with the smaller kidney and glomeruli sizes in APC1638T mice than in WT mice. 


\subsection{Morphological Characteristics of Podocyte of APC Mutant Mice with PAN-Induced} Nephrotic Syndrome

APC binds to the plus end of the microtubules and F-actin located in the basal plasma membrane and is involved in cytoskeleton regulation in highly polarized epithelial cells $[28,37]$. In contrast, Ninein binds to the minus end of the microtubules near the apical membrane [38]. Under normal conditions, there were no obvious changes in the podocytes of APC1638T mice. When nephrotic syndrome was induced in WT mice, endocytosis vesicles in the basal region of podocytes and transcytosis vesicles in the podocytes increased (Figure 5), which is consistent with our previous report of increased endocytosis vesicles in the podocytes in association with motor proteins, including cytoplasmic dynein-1, myosin 7 and myosin 9 [22]. Interestingly, endocytosis vesicles were reduced from basal membrane, and tubular structures were enlarged around the Golgi apparatus in APC1638T mice with PAN nephrotic syndrome in the present study (Figure 5). PAN is a transfer RNA mimetic that is incorporated into nascent polypeptides and inhibits translation and protein synthesis [39], resulting in the accumulation of incomplete polypeptides in the enlarged tubular structure around the Golgi apparatus, especially in APC1638T mice. The nerve growth factor (NGF)-induced transport of different cargos requires local synthesis of different dynein cofactors; the microtubule plus-end tracking protein APC binds with the dynein cofactor Lis1 to transport large vesicles, whereas Lis1 and p150(Glued) transport smaller signaling endosomes via axonal transport [40]. Similarly, in podocytes, the inability to bind the positive end of the microtubule to dynein was suggested to potentially suppress vesicle transport and thereby reduce the number of vesicles in the basal area of podocytes in the present study (Figure 10). Moreover, the greater reduction in $\alpha$-tubulin and cytoplasmic dynein-1 in podocytes of APC mutant mice with nephrotic syndrome than in WT mice with nephrotic syndrome (Figure 6) may result in a decrease in vesicle transport and albuminuria in APC C-terminal mutant mice (Figure 10).
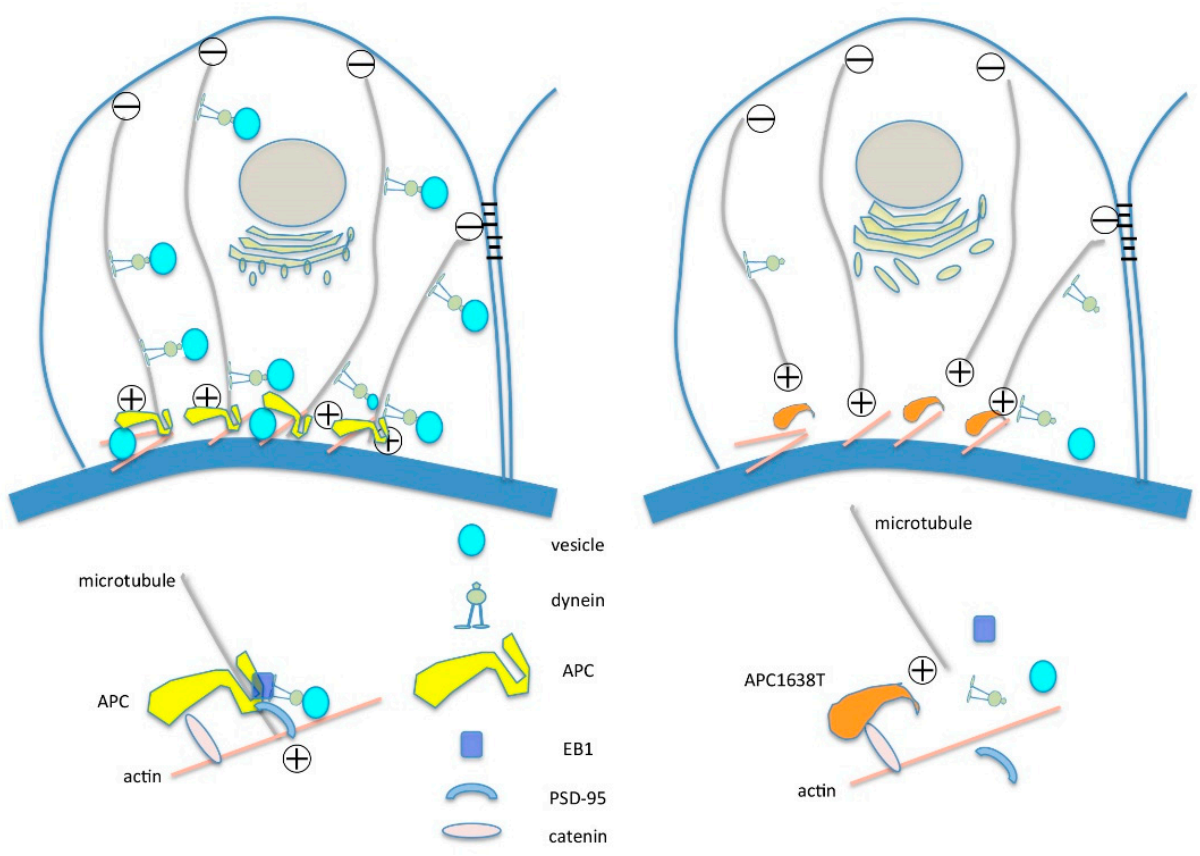

Figure 10. Illustration of molecular bindings of APC C-terminal with microtubule plus-end, PSD-95, EB-1 and cytoplasmic dynein-1 in the WT mice and APC1638T mice.

\subsection{APC as a Therapeutic Target of Selective Microalbuminuria}

The loss of negative charge and reduction in nephrin in the slit membrane with foot process effacement is a classical concept of selective proteinuria [41]; however, this concept cannot explain why albumin is selectively excreted without an increase in lowmolecular-weight protein in MCNS. As shown in Figure 9, the expression of nephrin and 
podocine did not change between WT and APC1638T mice in the normal condition, but they were reduced in both mice after PAN-induced nephrotic syndrome induction, merely reflecting the reduction in the number of slit membranes by foot process effacement that was observed to the same extent in both mice (Figure 5). These results indicate that slit membrane cannot explain the reduction of selective albuminuria in the APC1638T mice with PAN-induced nephropathy. Moreover, apoptosis markers including caspase- 3 and Fas-Ligand did not stain significantly in the podocytes of these mice (Figure 9), indicating that podocyte detachment may not have a major role in the PAN-induced nephrotic syndrome model. The recent concept of podocyte vesicle transcytosis via albumin receptors, including FcRn [14], megalin [16] and caveolin [17], or via macropinocytosis, [18] requires a vesicle transport system and motor proteins [19]. We have previously observed that these vesicles in the podocytes contained albumin by immunoelectron microscopy $[13,14]$. Blocking of albumin receptor via anti-FcRn antibody reduced albuminuria by about $50 \%$ in vivo [14]. Furthermore, blocking of megalin-mediated endocytosis by gentamycin reduced podocyte albumin endocytosis according to intravital imaging, but albuminuria was not evaluated [16]. Blocking caveolin-mediated albumin endocytosis via nystatin [17], blocking of fluid-phase endocytosis via the aquaporin inhibitor $\mathrm{pCMB}$, and cytochalasin $\mathrm{D}$ inhibiting actin polymerization [18] reduced albumin endocytosis in culture podocytes, but no data concerning in vivo albuminuria were available.

In the present study, we showed that APC C-terminal-depleted mice had reduced albuminuria in vivo. Under conditions of PAN-induced nephrotic syndrome, $\alpha$-tubulin and cytoplasmic dynein-1 levels were increased in podocytes in WT mice with enhanced albuminuria, which is consistent with the findings of our previous study [22]. In contrast, endocytosis vesicles were unable to bind to the microtubule plus end or cytoplasmic dynein cofactor, as the APC C-terminal was lacking [40], resulting in the reduction of podocyte vesicle transport containing albumin (Figure 10). The regulation of binding of APC with microtubules and dynein- 1 in the podocyte can be a molecular target of treatment of selective albuminuria in MCNS. Further studies will be required to clarify the specific role of APC in podocyte vesicle transport in nephrotic syndrome.

\section{Materials and Methods}

\subsection{Animal Experiments}

A total of eight 1-week-old male mice expressing APC1638T lacking the C-terminal with a microtubule-binding site (APC1638T mice) and their background WT C57BL/6JJmsSlc mice (Japan SLC, Hamamatsu, Japan) were harvested in a laboratory of Gifu University [42]. Four mice of each group had ad libitum access to tap water and standard mouse chow. MCNS was induced by administering puromycin aminonucleoside (PAN, Sigma Chemical Co., St. Louis, MO, USA) at $500 \mathrm{mg} / \mathrm{kg}$ body weight (BW) to WT and APC1638T mice. After 7 to 14 days, urinary protein levels were checked by a dipstick test to confirm nephrotic syndrome; 24-h urine samples were collected using metabolic cages, and urinary protein was analyzed by sodium dodecyl sulfate-polyacrylamide gel electrophoresis (SDS-PAGE, Invitrogen Waltham, MS, USA) with densitometry using ImageJ 1.53a software (NIH, Bethesda, MD, USA). After anesthesia, the kidneys were removed, and half of the kidney was immersion-fixed with $10 \%$ formalin for PAS staining and immunohistochemistry, while the other half was fixed with 2.5\% glutaraldehyde for electron microscopy (JEM-1011, JEOL, Tokyo, Japan).

\subsection{Periodic Acid Schiff (PAS) Staining, Immunohistochemistry and Image Analyses}

Paraffin-embedded tissues were cut to $2-\mu \mathrm{m}$ thickness and subjected to PAS staining. Immunohistochemistry was performed as previously described $[33,43]$. The number of podocyte nuclei were counted in the glomeruli cut near the center. The specialist of renal morphology (AT) counted the nuclei of podocyte by Toluidine blue staining of EPONembedded renal sections. Podocytes were easily identified by their location outside of capillary wall, which was also confirmed by immunostaining for podocalyxin, as we have 
shown previously [44]. Sections (2- $\mu \mathrm{m}$ thick) were incubated with polyclonal antibodies against cytoplasmic dynein-1 or $\alpha$-tubulin (Abcam, Tokyo, Japan) at 1:200 dilution followed by incubation with HRP-conjugated anti-rabbit Ig (Dako, Glostrup, Denmark) at 1:100 dilution, and immunoreactivity was detected by a DAB reaction.

Immunoreactivity of cytoplasmic dynein-1 or $\alpha$-ubulin was analyzed using Image-Pro plus version 5.0 (Media Cybernetics, Inc., Silver Spring, MD, USA), and the area $\times$ density of immunoreactivity in the podocytes in each glomerulus was calculated in 60 total glomeruli cut in the center.

Immunofluorescence were performed in paraffine embedded sections using direct Alexa Fluor labeled antibodies against nephrin (Alexa 680) and podocin (Alexa 546) for slit membrane, or caspase 3 (Alexa 488) and FAS-Ligand (Alex 594) for apoptosis (Life Science Marketplace/Szabo Scandic, Wienna, Austria). Multiple fluorescences were observed using Mantra 2 system (Kiko Tech Co., Ltd., Osaka, Japan).

\subsection{Electron Microscopy (EM)}

Part of the cortex of the kidney was fixed with $2.5 \%$ glutaraldehyde (TAAB, Berks,

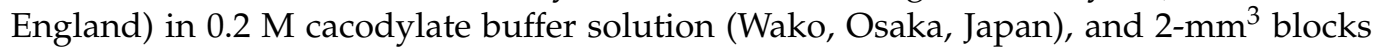
were cut and post-fixed with osmium tetroxide and embedded in epoxy resin (TAAB), as previously described [13]. The semi-thin sections were cut and stained with Toluidine blue to evaluate the glomerular area and number of podocytes in 5 to 10 blocks per mouse. The ultrathin sections were then cut with an ultramicrotome and counterstained with uranium acetate and lead citrate and observed under a transmission electron microscope (JEM-1011: JEOL, Tokyo, Japan).

\subsection{Quantitative Real-Time PCR}

Total RNA from kidneys was extracted using TRIZOL reagent (Invitrogen, Walthum, MS, USA) as described previously [45]. One microgram of total RNA per sample was subjected to reverse transcription to obtain single-stranded complementary DNA using the TaKaRa RNA PCR Kit Ver. 3.0 (TaKaRa BIO, Shiga, Japan) with a TaKaRa PCR Thermal Cycler 480. Complementary DNA levels of mouse tubulin $\alpha 1 a$, and dync1h were measured using Taq Man Universal Master Mix 2 or PowerUp SYBR Green Master Mix with an Applied Biosystems 7300 Real-Time PCR System (Thermo Fisher Scientific, Tokyo, Japan). The primers used in the present study are shown in Table 1. Relative quantification values of the target were normalized to the value of GAPDH as an endogenous control.

Table 1. Primers for real-time PCR.

\begin{tabular}{cc}
\hline Gene & \multicolumn{1}{c}{${\text { Sequences } \mathbf{5}^{\prime} \text { to } \mathbf{3}^{\prime}}^{\text {Dequc1h }}$} \\
\hline \multirow{2}{*}{ tubulinAlpha1a } & $\begin{array}{c}\text { Forward AGTCACAGGTCTGAAGCTCC } \\
\text { Reverse ACTGTGGAGATGGCATTGGA }\end{array}$ \\
\hline \multirow{2}{*}{ GAPDH } & $\begin{array}{c}\text { Forward AGCGGCTCTCTGTGGATTAC } \\
\text { Reverse CAACCACAGCAGTGGAAACC }\end{array}$ \\
\hline & $\begin{array}{c}\text { Forward ACCCAGAAGACTGTGGATGG } \\
\text { Reverse GGATGCAGGGATGATGTTCT }\end{array}$ \\
\hline
\end{tabular}

\subsection{Statistical Analyses}

The data were expressed as the mean \pm standard error. An analysis of variance was used for statistical comparisons between two groups, followed by a Bonferroni post-hoc analysis. $p$ values of $<0.05$ were considered to indicate statistical significance.

\section{Limitations}

In this study, we were unable to show direct molecular interactions between APC, cytoplasmic dynein $1, \alpha$-tubulin and podocyte vesicles. Recently, the intracellular signaling pathway of glomerular filtration barrier, actin, and Rho GTPase has been elucidated [46], 
and the signaling pathway of transcytosis in podocyte vesicles should be evaluated in future studies. It is also a limitation of this study that we could not harvest enough APC1638T mice for this experiment; thus, the repeated study needs to have enough animals for statistics or to use some other studies blocking APC C terminal by the antibody to confirm our observation.

\section{Conclusions}

It is possible that APC C terminal mutant mice could decrease albuminuria associated with a decrease in podocyte vesicle transport with a reduction in cytoplasmic dynein-1 and $\alpha$-tubulin when minimal change nephrotic syndrome is induced.

Author Contributions: Conceptualization, A.T. and T.S.; methodology, H.S. and N.O.Y.; software, S.H.; validation, S.H., A.T. and T.I.; formal analysis, S.H.; investigation, A.T., H.S. and N.O.Y. resources, T.S. and T.I.; data curation, S.H.; writing-original draft preparation, S.H. and A.T.; writing-review and editing, A.T. and T.I.; visualization, A.T.; supervision, A.T., T.S. and T.I.; project administration, A.T.; funding acquisition, A.T. All authors have read and agreed to the published version of the manuscript.

Funding: This work was partly funded by research donations from Naohiko Kobayashi of the Kobayashi Internal Medicine Clinic (\#2019-8, \#2020-9).

Institutional Review Board Statement: All of the procedures were conducted in accordance with the Guidelines for Animal Experimentation in Dokkyo Medical University and approved by the Medical Experimental Animal Ethics Committee of Dokkyo Medical (17-918; 1192) as well as by the Committee for Ethics in Animal Experimentation at Gifu University, which are in accordance with the "principles of laboratory animal care" (NIH publication No. 86-23, revised 1985).

Informed Consent Statement: Not applicable.

Data Availability Statement: The data used to support the findings of this study are available from the corresponding author upon request.

Acknowledgments: We thank Kyoko Mamada, Noriko Oshima and Kazumi Akimoto of the Center for Research Support, Dokkyo Medical University, for their support in performing urinary SDS-PAGE, Western blotting, and immunostaining. We also thank Kinichi Matsuyama and Minami Shimada of the Department of Pathology, Dokkyo Medical University, for their excellent help in performing electron microscopy.

Conflicts of Interest: The authors declare no conflict of interest associated with this work.

\section{References}

1. Yamada, E. The fine structure of the renal glomerulus of the mouse. J. Biophys. Biochem. Cytol. 1955, 1, 551-566. [CrossRef] [PubMed]

2. Rinehart, J.F. Fine structure of renal glomerulus as revealed by electron microscopy. AMA Arch. Pathol. 1955, 59, 439-448. [PubMed]

3. Farquhar, M.G.; Wissig, S.L.; Palade, G.E. Glomerular permeability. I. Ferritin transfer across the normal glomerular capillary wall. J. Exp. Med. 1961, 113, 47-66. [CrossRef]

4. Rodewald, R.; Karnovsky, M.J. Porous substructure of the glomerular slit diaphragm in the rat and mouse. J. Cell Biol. 1974, 60, 423-433. [CrossRef] [PubMed]

5. Ruotsalainen, V.; Ljungberg, P.; Wartiovaara, J.; Lenkkeri, U.; Kestila, M.; Jalanko, H.; Holmberg, C.; Tryggvason, K. Nephrin is specifically located at the slit diaphragm of glomerular podocytes. Proc. Natl. Acad. Sci. USA 1999, 96, 7962-7967. [CrossRef]

6. Tryggvason, K.; Wartiovaara, J. Molecular basis of glomerular permselectivity. Curr. Opin. Nephrol. Hypertens. 2001, 10, 543-549. [CrossRef]

7. Wartiovaara, J.; Ofverstedt, L.G.; Khoshnoodi, J.; Zhang, J.J.; Makela, E.; Sandin, S.; Ruotsalainen, V.; Cheng, R.H.; Jalanko, H.; Skoglund, U.; et al. Nephrin strands contribute to a porous slit diaphragm scaffold as revealed by electron tomography. J. Clin. Investig. 2004, 114, 1475-1483. [CrossRef] [PubMed]

8. Jarad, G.; Cunningham, J.; Shaw, A.S.; Miner, J.H. Proteinuria precedes podocyte abnormalities in Lamb2(-/-) mice, implicating the glomerular basement membrane as an albumin barrier. J. Clin. Investig. 2006, 116, 2272-2279. [CrossRef]

9. Farquhar, M.G. The glomerular basement membrane: Not gone, just forgotten. J. Clin. Investig. 2006, 116, 2090-2093. [CrossRef]

10. Smithies, O. Why the kidney glomerulus does not clog: A gel permeation/diffusion hypothesis of renal function. Proc. Natl. Acad. Sci. USA 2003, 100, 4108-4113. [CrossRef] 
11. Tojo, A. The role of the kidney in protein metabolism: The capacity of tubular lysosomal proteolysis in nephrotic syndrome. Kidney Int. 2013, 84, 861-863. [CrossRef]

12. Moeller, M.J.; Tenten, V. Renal albumin filtration: Alternative models to the standard physical barriers. Nat. Rev. Nephrol. 2013, 9, 266-277. [CrossRef] [PubMed]

13. Tojo, A.; Onozato, M.L.; Kitiyakara, C.; Kinugasa, S.; Fukuda, S.; Sakai, T.; Fujita, T. Glomerular albumin filtration through podocyte cell body in puromycin aminonucleoside nephrotic rat. Med. Mol. Morphol. 2008, 41, 92-98. [CrossRef] [PubMed]

14. Kinugasa, S.; Tojo, A.; Sakai, T.; Tsumura, H.; Takahashi, M.; Hirata, Y.; Fujita, T. Selective albuminuria via podocyte albumin transport in puromycin nephrotic rats is attenuated by an inhibitor of NADPH oxidase. Kidney Int. 2011, 80, 1328-1338. [CrossRef] [PubMed]

15. Soda, K.; Balkin, D.M.; Ferguson, S.M.; Paradise, S.; Milosevic, I.; Giovedi, S.; Volpicelli-Daley, L.; Tian, X.; Wu, Y.; Ma, H.; et al. Role of dynamin, synaptojanin, and endophilin in podocyte foot processes. J. Clin. Investig. 2012, 122, 4401-4411. [CrossRef]

16. Schiessl, I.M.; Hammer, A.; Kattler, V.; Gess, B.; Theilig, F.; Witzgall, R.; Castrop, H. Intravital Imaging Reveals Angiotensin II-Induced Transcytosis of Albumin by Podocytes. J. Am. Soc. Nephrol. 2016, 27, 731-744. [CrossRef]

17. Dobrinskikh, E.; Okamura, K.; Kopp, J.B.; Doctor, R.B.; Blaine, J. Human podocytes perform polarized, caveolae-dependent albumin endocytosis. Am. J. Physiol. Renal Physiol. 2014, 306, F941-F951. [CrossRef]

18. Chung, J.J.; Huber, T.B.; Godel, M.; Jarad, G.; Hartleben, B.; Kwoh, C.; Keil, A.; Karpitskiy, A.; Hu, J.; Huh, C.J.; et al. Albuminassociated free fatty acids induce macropinocytosis in podocytes. J. Clin. Investig. 2015, 125, 2307-2316. [CrossRef] [PubMed]

19. Tojo, A. Mechanism Underlying Selective Albuminuria in Minimal Change Nephrotic Syndrome. Int. J. Nephrol. 2019, 2019, 5859102. [CrossRef]

20. Farquhar, M.G.; Vernier, R.L.; Good, R.A. Studies on familial nephrosis. II. Glomerular changes observed with the electron microscope. Am. J. Pathol. 1957, 33, 791-817. [PubMed]

21. Farquhar, M.G.; Vernier, R.L.; Good, R.A. An electron microscope study of the glomerulus in nephrosis, glomerulonephritis, and lupus erythematosus. J. Exp. Med. 1957, 106, 649-660. [CrossRef]

22. Tojo, A.; Hatakeyama, S.; Kinugasa, S.; Fukuda, S.; Sakai, T. Enhanced podocyte vesicle transport in the nephrotic rat. Med. Mol. Morphol. 2017, 50, 86-93. [CrossRef]

23. Rishal, I.; Fainzilber, M. Axon-soma communication in neuronal injury. Nat. Rev. Neurosci. 2014, 15, 32-42. [CrossRef] [PubMed]

24. Gibbs, K.L.; Greensmith, L.; Schiavo, G. Regulation of Axonal Transport by Protein Kinases. Trends Biochem. Sci. 2015, 40, 597-610. [CrossRef] [PubMed]

25. Powell, S.M.; Zilz, N.; Beazerbarclay, Y.; Bryan, T.M.; Hamilton, S.R.; Thibodeau, S.N.; Vogelstein, B.; Kinzler, K.W. Apc Mutations Occur Early during Colorectal Tumorigenesis. Nature 1992, 359, 235-237. [CrossRef] [PubMed]

26. Brakeman, J.S.F.; Gu, S.H.; Wang, X.B.; Dolin, G.; Baraban, J.M. Neuronal localization of the Adenomatous polyposis coli tumor suppressor protein. Neuroscience 1999, 91, 661-672. [CrossRef]

27. Temburni, M.K.; Rosenberg, M.M.; Pathak, N.; McConnell, R.; Jacob, M.H. Neuronal nicotinic synapse assembly requires the adenomatous polyposis coli tumor suppressor protein. J. Neurosci. 2004, 24, 6776-6784. [CrossRef]

28. Mogensen, M.M.; Tucker, J.B.; Mackie, J.B.; Prescott, A.R.; Nathke, I.S. The adenomatous polyposis coli protein unambiguously localizes to microtubule plus ends and is involved in establishing parallel arrays of microtubule bundles in highly polarized epithelial cells. J. Cell Biol. 2002, 157, 1041-1048. [CrossRef]

29. Smits, R.; Kielman, M.F.; Breukel, C.; Zurcher, C.; Neufeld, K.; Jagmohan-Changur, S.; Hofland, N.; van Dijk, J.; White, R.; Edelmann, W.; et al. Apc1638T: A mouse model delineating critical domains of the adenomatous polyposis coli protein involved in tumorigenesis and development. Genes Dev. 1999, 13, 1309-1321. [CrossRef]

30. Kakinuma, N.; Nishimura, Y.; Akiyama, T.; Senda, T. APC is colocalized with beta-catenin and hDLG in Henle's loop of the mouse kidney. Acta Histochem. Cytochem. 2000, 33, 457-463. [CrossRef]

31. Senda, T.; Iizuka-Kogo, A.; Onouchi, T.; Shimomura, A. Adenomatous polyposis coli (APC) plays multiple roles in the intestinal and colorectal epithelia. Med. Mol. Morphol. 2007, 40, 68-81. [CrossRef]

32. Li, C.G.; Onouchi, T.; Hirayama, M.; Sakai, K.; Matsuda, S.; Yamada, N.O.; Senda, T. Morphological and functional abnormalities of hippocampus inAPC(1638T/1638T)mice. Med. Mol. Morphol. 2021, 54, 31-40. [CrossRef]

33. Tojo, A.; Bredt, D.S.; Wilcox, C.S. Distribution of postsynaptic density proteins in rat kidney: Relationship to neuronal nitric oxide synthase. Kidney Int. 1999, 55, 1384-1394. [CrossRef] [PubMed]

34. Chen, S.; Kasama, Y.; Lee, J.S.; Jim, B.; Marin, M.; Ziyadeh, F.N. Podocyte-derived vascular endothelial growth factor mediates the stimulation of alpha 3(IV) collagen production by transforming growth factor-beta 1 in mouse podocytes. Diabetes 2004, 53, 2939-2949. [CrossRef]

35. Alsabban, A.H.; Morikawa, M.; Tanaka, Y.; Takei, Y.; Hirokawa, N. Kinesin Kif3b mutation reduces NMDAR subunit NR2A trafficking and causes schizophrenia-like phenotypes in mice. EMBO J. 2020, 39, e101090. [CrossRef] [PubMed]

36. Wang, T.Y.; Onouchi, T.; Yamada, N.O.; Matsuda, S.; Senda, T. A disturbance of intestinal epithelial cell population and kinetics in APC1638T mice. Med. Mol. Morphol. 2017, 50, 94-102. [CrossRef] [PubMed]

37. Nathke, I.S.; Adams, C.L.; Polakis, P.; Sellin, J.H.; Nelson, W.J. The adenomatous polyposis coli tumor suppressor protein localizes to plasma membrane sites involved in active cell migration. J. Cell Biol. 1996, 134, 165-179. [CrossRef]

38. Mogensen, M.M.; Malik, A.; Piel, M.; Bouckson-Castaing, V.; Bornens, M. Microtubule minus-end anchorage at centrosomal and non-centrosomal sites: The role of ninein. J. Cell Sci. 2000, 113, 3013-3023. [CrossRef] 
39. Schmidt, E.K.; Clavarino, G.; Ceppi, M.; Pierre, P. SUnSET, a nonradioactive method to monitor protein synthesis. Nat. Methods 2009, 6, 275-277. [CrossRef]

40. Villarin, J.M.; McCurdy, E.P.; Martinez, J.C.; Hengst, U. Local synthesis of dynein cofactors matches retrograde transport to acutely changing demands. Nat. Commun. 2016, 7, 13865. [CrossRef] [PubMed]

41. Haraldsson, B.; Nystrom, J.; Deen, W.M. Properties of the glomerular barrier and mechanisms of proteinuria. Physiol. Rev. 2008, 88, 451-487. [CrossRef] [PubMed]

42. Yamada, N.O.; Wenduerma, S.; Matsuda, S.; Senda, T. Validation and application of a novel APC antibody in western blotting, immunoprecipitation, and immunohistochemistry. Med. Mol. Morphol. 2018, 51, 227-236. [CrossRef]

43. Tojo, A.; Asaba, K.; Kinugasa, S.; Ikeda, Y.; Shintani, Y.; Fukayama, M.; Nangaku, M. The reduced expression of proximal tubular transporters in acquired Fanconi syndrome with kappa light chain deposition. Med. Mol. Morphol. 2016, 49, 48-52. [CrossRef] [PubMed]

44. Hanamura, K.; Tojo, A.; Fujita, T. Urinary and glomerular podocytes in patients with chronic kidney diseases. Clin. Exp. Nephrol. 2014, 18, 95-103. [CrossRef] [PubMed]

45. Satonaka, H.; Nagata, D.; Takahashi, M.; Kiyosue, A.; Myojo, M.; Fujita, D.; Ishimitsu, T.; Nagano, T.; Nagai, R.; Hirata, Y. Involvement of P2Y(12) receptor in vascular smooth muscle inflammatory changes via MCP-1 upregulation and monocyte adhesion. Am. J. Physiol. Heart Circ. Physiol. 2015, 308, H853-H861. [CrossRef]

46. Asano-Matsuda, K.; Ibrahim, S.; Takano, T.; Matsuda, J. Role of Rho GTPase Interacting Proteins in Subcellular Compartments of Podocytes. Int. J. Mol. Sci. 2021, 22, 3656. [CrossRef] [PubMed] 